\title{
THE HUMAN IMPACT \\ AND THE AQUATIC BIODIVERSITY \\ OF LAKE BOSOMTWE: \\ RENNAISANCE OF THE CULTURAL TRADITIONS \\ OF ABONO (GHANA)?
}

\begin{abstract}
Dickson ADOM*
* Department of General Art Studies, Kwame Nkrumah University of Science and Technology, Kumasi, Ghana, P.O. BOX NT 1, adomdick@yahoo.com
\end{abstract}

DOI: 10.1515/trser-2018-0007 traditions.

KEYWORDS: aquatic biodiversity, lake Bosomtwe, human impacts, cultural

\begin{abstract}
The lake Bosomtwe in the Abono Village in the Ashanti Region of Ghana is in a deplorable state, thereby negatively affecting its rich aquatic biodiversity. The condition is blamed on the negative human impacts on the lake. A phenomenological study of the qualitative approach was undertaken to investigate this phenomenon. The findings revealed that the deteriorating condition of the lake is due to the weak implementation of the cultural traditions of the Abono people. The study proposes the strict observance of the cultural traditions as a complement to the scientific models to avert the want and destruction of the aquatic biodiversity of lake Bosomtwe of Ghana.
\end{abstract}

RÉSUMÉ: L’impact humain et la biodiversité aquatique du Lac Bosomtwe: renaissance des traditions culturelles d'Abono (Ghana)?

Le Lac Bosomtwe du village d'Abono dans la région d'Ashanti de Ghana se trouve dans un état déplorable, ce qui a un impact négatif sur sa riche biodiversité aquatique. L’état du lac est dû à l'impact humain négatif. Afin d'étudier ce phénomène, une étude phénoménologique d'approche qualitative a été mise en place. Les conclusions ont mises en évidence le fait que l'état de détérioration du lac est dû à la faible mise en oeuvre des traditions culturelles du peuple Abono. L'étude propose le strict respect des traditions culturelles, ainsi que des modèles scientifiques afin d'éviter la destruction aveugle de la biodiversité aquatique du Lac Bosomtwe de Ghana.

REZUMAT: Impactul antropic şi biodiversitatea acvatică a Lacului Bosomtwe: renaștere a tradițiilor culturale din Abono (Ghana)?

Lacul Bosomtwe din satul Abono în regiunea Ashanti din Ghana se află într-o stare deplorabilă, ceea ce afectează negativ bogata biodiversitate acvatică. Starea lacului este pusă pe seama impactului antropic negativ. Pentru a cerceta acest fenomen, s-a efectuat un studiu fenomenologic cu abordare calitativă. Concluziile au pus în evidență că deteriorarea stării lacului se datorează slabei implementări a tradițiilor culturale ale populației Abono. Studiul propune respectarea cu strictețe a tradițiilor culturale în plus față de modelele științifice pentru a evita distrugerea prin neglijență a biodiversității acvatice al Lacului Bosomtwe din Ghana. 


\section{INTRODUCTION}

Aquatic biodiversity is defined as the diversity of plant and animal populations in the aquatic ecosystems such as rivers, lakes, ponds, oceans, bays, marshes and swamps (Helfrich et al., 2009). This diversity of life has been the sole sustaining force for generations (Adom et al., 2017). Bradley et al. (2012) concur the aquatic biodiversity offers humans their basic necessities of life; food, clothing and shelter. In fact, aquatic biodiversity present in all the aquatic ecosystems has a very significant role to support and make life on the planet possible. Helfrich et al. (2009) sums up the benefits including the provision of jobs via the tourism potentials of aquatic ecosystem as ecotourism, buffer against new diseases, ensuring food security and the massive reduction of carbon dioxide to improve the atmospheric condition of the earth. Due to the indispensable roles and relevance of aquatic biodiversity, there is an urgent need to conserve and sustain them. It is sobering, the global estimates of the depletion of the aquatic biodiversity are astronomical (WWF, 2016). Therefore, Adom (2016a, b) noted recently the resurgent interests of both international and national bodies to look for feasible strategies for arresting this deleterious state of aquatic biodiversity that supports life. The sustainability of the aquatic biodiversity is essential to the general well being of the environment and human life because both depend on the aquatic life and their quintessential ecological functions for life survival (Helfrich et al., 2009; Adom et al., 2017).

There are several established factors that have caused the abysmal decline in the aquatic biodiversity globally that threaten the survival of life on Earth (Hogan, 2010; Shah, 2014). Paramount amongst these causative factors is the anthropogenic factors, particularly, the impacts of human activities, labelled as a critical environmental issue (National Research Council, 1995, in Lamptey, 2015; Khoshnood, 2017). This condition was foreseen due to the growing population rate, especially in the Africa sub-region (Harden, 1968). Orighabor (2016) noticed that human activities in various forms ranging from poor agricultural, domestic and industrial activities to the bad disposal of sewage and pollutants are detrimental to the aquatic life and resources in the various aquatic ecosystems.

The state of the aquatic biodiversity in the largest, natural lake in West Africa, lake Bosomtwe, is in a deplorable state due to unbridle and poor management of human activities. These include Illegal housing construction (Mohammed, 2014); crop cultivation and deforestation of the vegetation (Adu-Boahen et al., 2015); over fishing, pastoral farming and waste disposal (Abreu et al., 2016). There have been many suggestions put forward to curb the identified human impacts that are negatively affecting the state of aquatic biodiversity in the lake Bosumtwe Basin. For instance, Abreu et al. (2016) suggested the undertaking of modern scientific models in environmental management such as Environmental Impact Assessment (EIA) in every project undertaken at the catchment of the lake, using biological and ecological indicators such as the Macro-benthic invertebrates monitoring programme, physical, chemical and bacteriological assessment and water quality parameters assessment, to arrest the canker of human impacts from destroying the aquatic biodiversity of the lake. Towing the purely scientific conservation strategy, Adu-Boahen et al. (2015) recommended the re-planting of native vegetation to check and arrest soil erosion as well as strict cautioning against the unbridled application of chemical fertilizers in agricultural activities undertaken in the lake Bosumtwe Catchment. Admittedly, these scientific conservation strategies are very effective in controlling the abuse of aquatic biodiversity in any region. However, an over-reliance on only the scientific models in a one lens approach cannot remedy the deleterious state of the abuse of the aquatic biodiversity (Adom et al., 2016a, b) as well as halt the negative human impacts that disturb the sanity of the lake Bosumtwe. There is the need to look for other alternatives to the implementation of the scientific strategies for more pluralistic approaches (Wilder et al., 2016). 
Scholars who have undertaken research projects in lake Bosomtwe have realized that the inhabitants in the close to sixty local communities (Abreu et al., 2016a, b) are traditional people (Dassah and Agbo, n.d.) whose worldviews are shaped and regulated largely by cultural traditions (Adom et al., 2016a, b). This is not misplaced because to the local residents around the lake Bosumtwe, believe that the lake, its origin and management, pivots on indigenous theories that are driven by cultural traditions such as religious beliefs, taboos, totemic system and norms. In such an environment where culture reigns high in monitoring the behavioural attitudes of residents, it would be very beneficial to look into the cultural traditions that regulated the attitudes of local residents around the lake Bosumtwe catchment, savouring the abuse of its rich taxas of aquatic biodiversity. This is keen because "the cultural traditions have a great affinity with environmental protection" (Adom, 2017). Researchers have realized that disregard for the customs, beliefs and norms (cultural traditions) that effectively monitored and curtailed all forms of negative human impacts by both the local residents and visitors who tour the site is the sole cause of the lake's sorry state (Mohammed, 2014; Lamptey, 2015; AduBoahen et al., 2015). This condition, which has caused the weakening of cultural traditions in strictly monitoring the activities of the people, raises many questions such as: what caused the relaxed implementation of the cultural traditions? How effective were these cultural traditions in protecting the aquatic biodiversity in the lake Bosumtwe in the past? Can there be a renaissance of those cultural traditions in the face of modernisation? How can these cultural traditions be harnessed to serve as an effective traditional strategy, as a synergy to the purely scientific models to salvage the deplorable state of the aquatic biodiversity in lake Bosumtwe?

Furnishing answers to these important questions would help in arresting the negative human impacts on the aquatic biodiversity while helping in redeeming its past glory. This research is informed by an early research in assessing the impacts of Asante indigenous knowledge in the local communities in the Asante Bekwai District, Ashanti Region of Ghana which falls within the catchment of the lake Bosumtwe (Adom, 2016a, b). The study revealed that cultural traditions still hold high currencies in the worldviews of the people and can be a viable tool in regulating their activities that are not favouring the lake. Therefore, a thorough and extensive study into these cultural traditions for new strategies to help regulate the human activities for especially the aquatic biodiversity (Anim et al., 2013) is needed. It is this academic gap in the various research projects that have been carried out in the lake Bosumtwe that is to be filled by the study. The study is driven by four main objectives: in Ghana;

1. To investigate into the human impacts on the aquatic biodiversity of lake Bosumtwe

2. To find out the influence of the cultural traditions of Abono on human activities that affects the aquatic biodiversity of lake Bosumtwe;

3. To suggest how the effective cultural traditions can be harnessed as a strategy to complement the scientific models to improve the state of the aquatic biodiversity of lake Bosumtwe. 
Precise information of this would truly inform the environment related institutions and interested people on how they can use the cultural traditions of the people in arresting the negative human impacts on the aquatic biodiversity of lake Bosumtwe. We suspect it would improve the aquatic biodiversity of the lake; increase its eco-tourism, boost the environmental health and atmospheric conditions of the lake basin while improving on the quality of life of the people through improved economy.

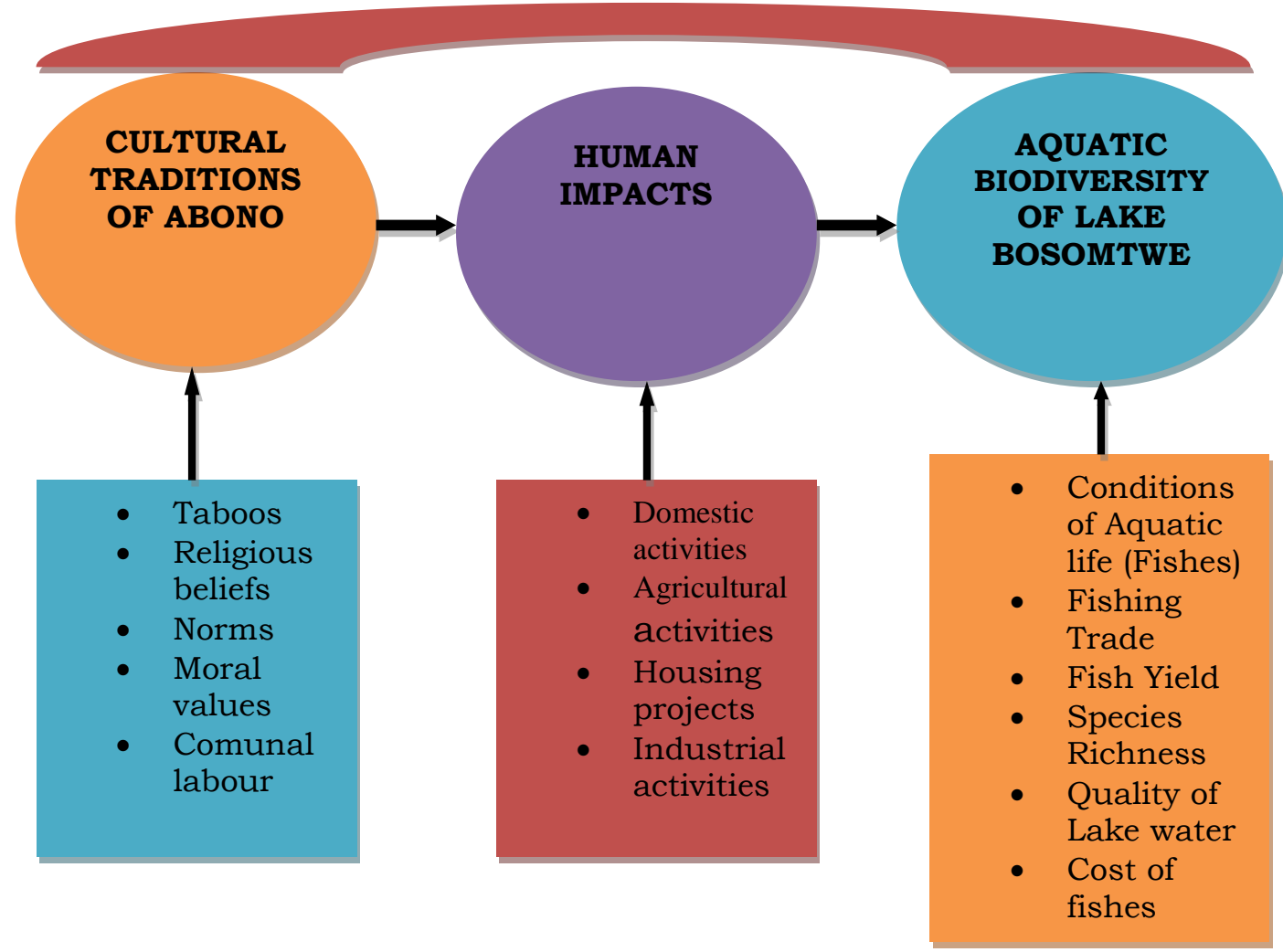

Figure 1: Conceptual framework for the study; researcher's construct from the field survey, 2017.

\section{MATERIAL AND METHODS}

The research was rooted in a cultural anthropology study at Abono (60 32'01.50'N; $1025^{\prime} 44.53$ ' W), the most populous and populated local community (Otu, 2010) amongst the sixty local communities around the lake Bosomtwe catchment in the Ashanti Region of Ghana. The study was undertaken over a ten month period from September 2016 to June 2017 to ascertain the impacts of human activities on the aquatic biodiversity of the lake and investigate into how the cultural traditions of Abono could be used as a strategy in curbing the negative activities of residents and visitors.

Due to the cultural and social context that characterizes the study, the qualitative study approach was utilized (Denzin and Lincoln, 1994). Two principal data collecting instruments in anthropology namely interviews (Personal and Focus Group Discussion) and observations (Direct) were used in soliciting for data on the state of the lake Bosomtwe as well as assessing the impacts of human activities and cultural traditions of the people of Abono on the aquatic biodiversity of the lake. The phenomenology research method was used by the researcher in 
seeking diverse views and thick description of the phenomenon under study (Leedy and Ormrod, 2010). A total of seven private interviews and twelve Focus Group Discussion interviews were conducted with a sample of sixty-five informants some of whom were purposively sampled while others were randomly sampled. The selection was made from a target population consisting of traditional authorities (Chiefs, Elders in the traditional council, traditional priest), fishermen, conservationists and residents of Abono (Tab. 1; Fig. 1).

Due to the particular characteristics of some of the traditional cultural elements like the revealing the sources of human impacts may not be told in public (Fraenkel et al., 2012), personal interviews were held for the head of the Bosomtwe Forest Reserve, the traditional priest, two leaders of the fishermen and two elderly respondents who are very knowledgeable in the cultural traditions surrounding the formation of the lake Bosomtwe.

The Focus Group Discussions aided in dissuading any pre-conceived and negative ideas about the intent of the research (Pope et al., 2000; Fraenkel et al., 2012) amongst the large rural populace while generating rich opinions from the fruitful discussions (Leedy and Ormrod, 2010). Direct observations for first hand information (Kumekpor, 2002) on the human impacts and their adverse effects on the aquatic biodiversity of the Bosomtwe Lake as well as the cultural traditions were made using a well designed observation checklist.

The purposive sampling was used for the selection of the traditional authorities, elders in the traditional council, elderly respondents above the age of 40, conservationists and fishermen. It was seen as the best sampling technique for selecting this section of the sample who were seen as possessing the unique features of the study objectives and very capable of offering the required data for the study. On the other hand, the youth respondents were randomly selected due to their high numbers and possession of somehow equal knowledge regarding the phenomenon under investigation. (Lewis and Sheppard, 2006; Leedy and Ormrod, 2010)

The Interpretative Phenomenological Analysis (IPA) was used for analyzing the rich data on the phenomena studied from the respondents. Thick quotations from the responses of informants were used in constructing the meanings of the data generated (Fade, 2004; Smith and Osborn, 2008; Pietkiewicz and Smith, 2014). Also, the conservation value of the cultural traditions as potent enough in curtailing the wanton abuse of the aquatic biodiversity in the Bosomtwe Lake was assessed using the model of Smith and Wishnie (2000). The keys in the model are assessing how the cultural traditions ensured:

1. The harvesting restraints of the fishes;

2. The protection of the resource species;

3 . The regulation of the onset/duration of harvests;

4. The avoidance of harmful habitat modification;

5. The patch-switching to maximize overall return. 
Table 1: Breakdown of interviewees; researcher's construct from the field survey, 2017 (Fig. 1).

\begin{tabular}{|c|c|c|c|}
\hline No. & $\begin{array}{c}\text { Category } \\
\text { of interviewee }\end{array}$ & $\begin{array}{l}\text { Total no. } \\
\text { selected }\end{array}$ & Details \\
\hline 1. & $\begin{array}{l}\text { Traditional } \\
\text { authorities }\end{array}$ & 4 & $\begin{array}{l}\text { The paramount chief of Abono } \\
\text { and his three sub-chiefs were } \\
\text { interviewed individually } \\
\text { (personal interview). }\end{array}$ \\
\hline 2. & $\begin{array}{l}\text { Elders } \\
\text { in the } \\
\text { Traditional } \\
\text { Council }\end{array}$ & 8 & $\begin{array}{l}\text { Eight elders that formed the } \\
\text { traditional cabinet of Abono were } \\
\text { interviewed in a two Focus } \\
\text { Group Discussion interview } \\
\text { sessions. }\end{array}$ \\
\hline 3. & $\begin{array}{c}\text { Religious } \\
\text { officials }\end{array}$ & 1 & $\begin{array}{l}\text { One traditional priest who } \\
\text { performs the periodic rituals in } \\
\text { the Bosomtwe Lake was } \\
\text { interviewed privately. }\end{array}$ \\
\hline 4. & Fishermen & 12 & $\begin{array}{l}\text { Two leaders of the fishermen } \\
\text { were interviewed privately while } \\
\text { the other ten including fish sellers } \\
\text { were interviewed in two Focus } \\
\text { Group Discussion interview } \\
\text { sessions. }\end{array}$ \\
\hline 5. & Conservationists & 6 & $\begin{array}{l}\text { The head of the Bosomtwe Forest } \\
\text { Reserve was privately } \\
\text { interviewed while the other five } \\
\text { conservationists were interviewed } \\
\text { in a Focus Group Discussion. }\end{array}$ \\
\hline 6. & $\begin{array}{l}\text { Elderly residents } \\
\text { (40 and above) }\end{array}$ & 34 & $\begin{array}{l}\text { Two elderly respondents were } \\
\text { interviewed privately while } 16 \\
\text { elderly respondents were } \\
\text { categorized into four Focus } \\
\text { Groups consisting of four elders } \\
\text { in each were interviewed. }\end{array}$ \\
\hline 7. & $\begin{array}{c}\text { Youth residents } \\
\text { (20 years }-39 \text { years) }\end{array}$ & 16 & $\begin{array}{l}\text { Sixteen youth were randomly } \\
\text { selected and interviewed in three } \\
\text { Focus Group Discussions. }\end{array}$ \\
\hline
\end{tabular}




\section{DESCRIPTION OF THE PROJECT AREA}

The research project was carried out at lake Bosomtwe and the Abono community close to the lake. The lake is the only natural inland freshwater lake in Ghana (Adu-Boahen et al., 2015) and the largest natural lake in West Africa (Abreu et al., 2016). Precisely in location, the Bosomtwe Lake is located about 30-35 km South-East of Kumasi, the capital of the Ashanti region at the very centre of Ghana (Asamoah et al., 2015). Almost 60 communities surround the lake with 24 being the main local communities with the other being small villages and towns. However, the populous and largest local community which is the easiest point to enter the lake premises from Kumasi is Abono (Dassah and Agbo, n.d.), where the study was carried out (Fig. 2). It has an estimated population of close to 1,500. There are four major seasons in the lake catchment; the early rainy season (May to July), the monsoon drought (July to August), the late rainy season (September to November) and the dry season (December to April). The temperature around the lake vicinity is usually high at an average of $26 \mathrm{C}$ and about $30^{\circ} \mathrm{C}$ between the months of March and April (Adu-Boahen et al., 2015) with the annual rainfall falling within the range of $1,500 \mathrm{~mm}$ and $1,800 \mathrm{~mm}$. Two types of soil are peculiar to the area. Gleyic Alisols covers approximately $55 \%$ of the land mass from the North to the North-Western parts while the South to the South-Eastern parts which is estimated at $45 \%$ is of the Ferric Acrisols soil (Abreu et al., 2016). Otu (2010) estimates the minimum height of the rim of the crater as $110 \mathrm{~m}$ above current water level which amounts to $99 \mathrm{~m}$ a.s.l.

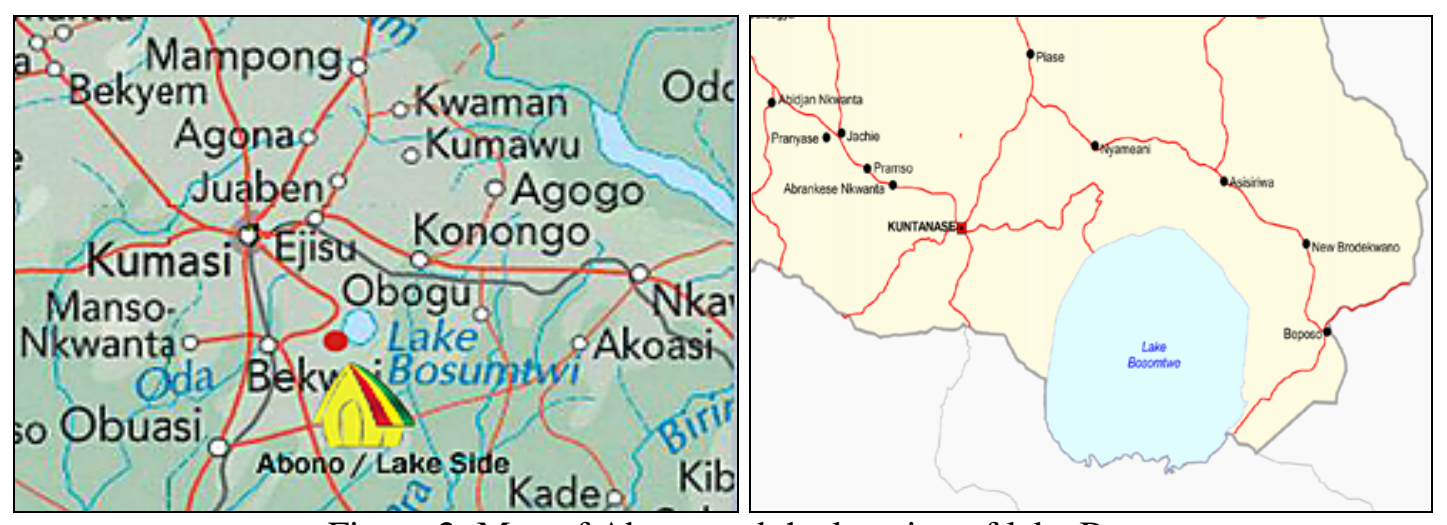

Figure 2: Map of Abono and the location of lake Bosomtwe

(http://www.africaguide.com).

The formation of the Bosomtwe Lake has two different perspectives. Scientifically, the lake is asserted to have been formed as a result of a meteorite impact forming the crater at the centre of a dense rain forest (Jones et al., 1981). Moon and Mason (1965) confirmed that this resulted in a volcanic eruption creating the dent which was gradually filled with water. That is the etymology of the name of the lake in the Asante language, Bosom (Deity), Twe (Antelope) meaning the lake is for the Deity (Bosomtwe). This probably explains the huge cultural traditions that monitored the management of the lake and the great impact of cultural traditions regarding the lake on the worldview of the local residents living in the surrounding local communities. 
The aquatic biodiversity in the Bosomtwe Lake is rich in species, especially freshwater fishes (Tab. 2) with global recognition (Abreu, et al., 2016). When the lake was not wantonly abused, nine genera of fishes belonging to five families and eleven species of fish were recorded (Whyte, 1975). These included the Barbus ablabe, Barbus trispilos, Roloffia petersii, Epiplatys chaperi, Amphilus ateseunsis, Heterobranchus isopterus, Chromi-dotilapia guntheri, Tilapia discolour (Kaenbre), Tilapia busumana (Paripari), Sarotherodon multifasciatus (Apatre fufuo) and Hemichromis fasciatus (Komfo). Abreu et al. (2016) noted in a recent study that Tilapia busumana is currently the only recorded endemic fish species in the lake. Tilapia fish, catfish and mud fish are the common fishes in the Bosomtwe Lake (Asamoah et al., 2015) while the jewel fish is rare.

Table 2: List of freshwater fishes in the lake Bosomtwe; author's construct adapted from List of Freshwater Fishes for Ghana from fish.mongabay.com/data/Ghana.htm

\begin{tabular}{|c|c|l|l|}
\hline \multicolumn{1}{|c|}{ Order } & Family & \multicolumn{1}{c|}{ Species } & \multicolumn{1}{c|}{ Status } \\
\hline Perciformes & Cichilae & Tilapia discolor & Native \\
\hline Perciformes & Cichilae & Tilapia zilli & Native \\
\hline Perciformes & Cichilae & $\begin{array}{l}\text { Chrpmidotilapia } \\
\text { geunteri geunteri }\end{array}$ & Native \\
\hline Perciformes & $\begin{array}{l}\text { Sarotherodon } \\
\text { galilaeus } \\
\text { multifasciatus }\end{array}$ & Native \\
\hline Perciformes & Cichilae & $\begin{array}{l}\text { Hemichromis } \\
\text { fasciatus }\end{array}$ & Native \\
\hline Cyprinodontiformes & Nothobranchiidae & Epiplatys chaperi & Native \\
\hline Cypriniformes & Cyprinidae & Barbus ablabes & Native \\
\hline Cypriniformes & Cyprinidae & Barbus trispilos & Native \\
\hline Siluriformes & Claridae & $\begin{array}{l}\text { Heterobranchus } \\
\text { isopterus }\end{array}$ & Native \\
\hline Siluriformes & Amphilidae & Amphilius atesuensis & Native \\
\hline Siluriformes & Claridae & $\begin{array}{l}\text { Heterobranchus } \\
\text { bidorsalis }\end{array}$ & Native \\
\hline
\end{tabular}

Interestingly, traditional equipments and tools are used for the main artisanal fishing activities. Wooden boat-like devices measuring about 18 feet are used as fishing crafts referred to by the fishermen as Padua, is used for fishing while small boxlike pieces of plywood are used for paddling. Three main fishing gears are used by the fishermen (Figs. 3-8). These are the wire mesh traps (Ensoa), the gill nets (Twee) $(25 \mathrm{~m} \times 2 \mathrm{~m}-3 \mathrm{~m})$ and cast nets (Twee Kese) (one m - two m) (Dassah and Agbo, n.d.). There are currently no indices to measure the yield of fish caught. However, it is estimated that 27 tons of fish are harvested in a day while about 2,720 kg are harvested every four hours (Dassah and Agbo, n.d.). These estimated figures are not constant and may dwindle considerably in varying seasons and the fishing pressure on the lake at any given fishing day. Rattan and palm frond woven containers are used as receptacles for keeping the harvested fishes before fish sellers come to purchase at the shores of the lake. 


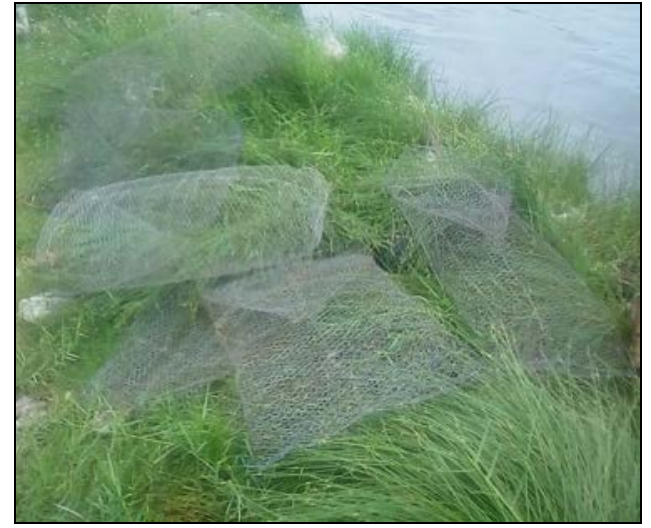

Figure 3: Wire Mesh Traps.

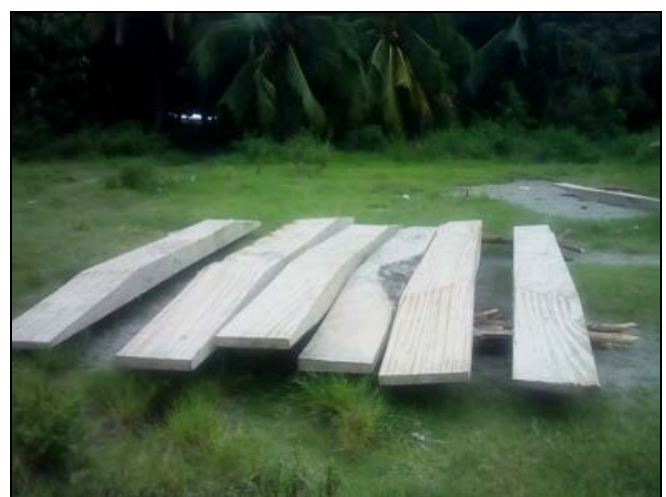

Figure 5: Wooden fishing craft (Padua).

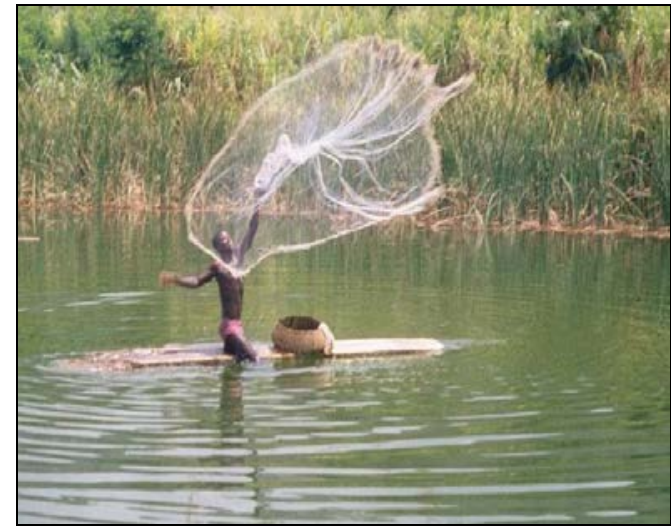

Figure 4: Cast Nets.

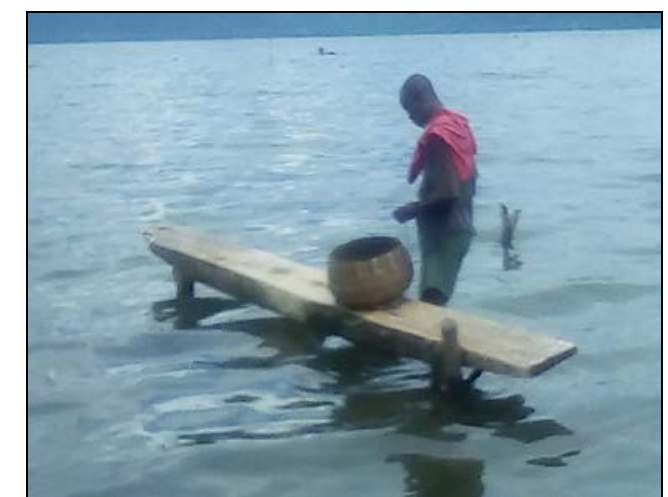

Figure 6: A fisherman with a container.

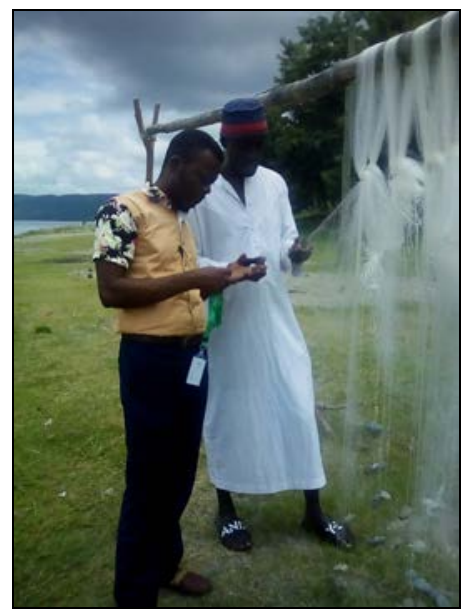

Figure 7: Author interviewing one of the leader of the fishermen in Abono.

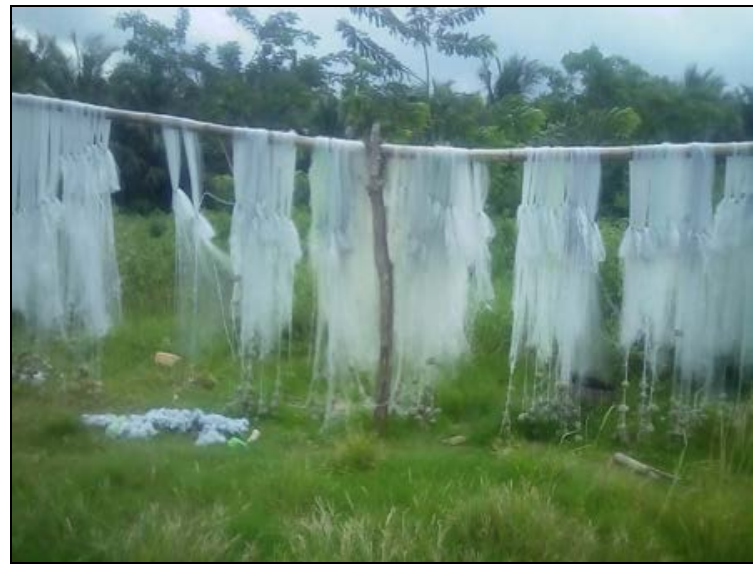

Figure 8: Gill nets used for fishing. 


\section{RESULTS AND DISCUSSION}

The findings and discussions of the research are discussed under three main headings, namely: the state of the aquatic biodiversity of Bosomtwe Lake, the human impacts on the aquatic biodiversity, and the cultural traditions of Abono and its impact on the use of aquatic biodiversity.

\section{The state of the aquatic biodiversity of lake Bosomtwe Species richness}

Lake Bosomtwe is a storehouse of a great variety of aquatic species. In terms of fisheries, there are currently four principal species out of the eleven species that were discovered by Whyte in 1975 that are common in the fishes that are caught by the fishermen. These are Tilapia discolour (Kaenbre), Tilapia busumana (Paripari), Sarotherodon galilaeus multifasciatus (Apatre fufuo), and Hemichromos fasciatus (Komfo). The other species are rare and fishermen chance on them, especially the species Roloffia petersii, and Epiplatys chaperi during the high peaks of rain during the months of June and July every year. The current state of species richness is very low as lamented by the leaders of the fishermen. In a personal interview, one of them informed the researcher that: "when I was ten years old, I used to go for fishing with my father who was the chief fisherman in Abono at that time. There were different kinds (species) of fishes of different nature, colours and so forth. It is distressing that today only three or four kinds (species) of fishes are captured by me and the other fishermen. I fear that all the fish species in our lake are dying out" (FL, Personal communication, 17 November, 2016).

Similar sentiments were expressed by the other fishermen and residents in the area. The chief women fish sellers in Abono who are now over eighty-five years disclosed to the researcher: "there were great varieties in the fishes that I used to buy from the fishermen when I was in my youthful exuberance. Tilapia discolour (Kaenbre), Tilapia busumana (Paripari), Sarotherodon galilaeus multifasciatus (Apatre fufuo) and Hemichromos fasciatus (Komfo) were very common. Today, the fishermen can't get many of them. It is only Apatre fufuo and Kaenbre that we sell” (FS, Personal Communication, 19 November, 2016).

The researcher and his assistants observed this situation in fifteen days direct observations of the species of fish that were captured by the fishermen. Many of the former species recorded are no more, probably endemic. Only few fish species mentioned earlier were recorded. This affirms the assertion made by Dassah and Agbo (n.d.) that roughly four species of fish, namely Tilapia busumana, Tilapia discolour, S. galilaeus multifasciatus and $H$. fasciatus.

\section{Fish sizes and fish yield}

All the respondents interviewed admitted that the sizes of the fishes as well as their yields have greatly dwindled. The largest size of the fish caught measured $25 \mathrm{~cm}$ length $\times 14.8$ $\mathrm{cm}$ wide, the medium size measured $16 \mathrm{~cm}$ length $\times 7.4 \mathrm{~cm}$ wide while the small fishes measured eight $\mathrm{cm}$ length $\times 3.9 \mathrm{~cm}$ wide. The fish yield, which used to be 27 tons of fish in a day, has reduced drastically to few tons of six to eight tons a day. Lamenting on the dwindling sizes and yield of fish, the fishermen in a focus group discussion said: "we used to fish about 40 big catches of fishes, but now we get less than 25 smaller-sized fishes in a 12 hour fishing expedition. They are greatly small in size that is why some of us are using very small meshed nets. If you do not use it, you will go home hungry and you would not get anything to cater for your family” (FFFS-FGD, Personal Communication, 25 November, 2016). 
The sizes of fishes and the sizes of the mesh of the nets that were used were below the allowed minimum size of $60 \mathrm{~mm}$ in the Fisheries Regulations (Fisheries Regulations of Ghana, 2010). Likewise, the small fishes below the length of $14 \mathrm{~cm}$ (Fig. 9) banned by the Fisheries Ministry were caught by the fishermen because of poverty and the great need to survive.

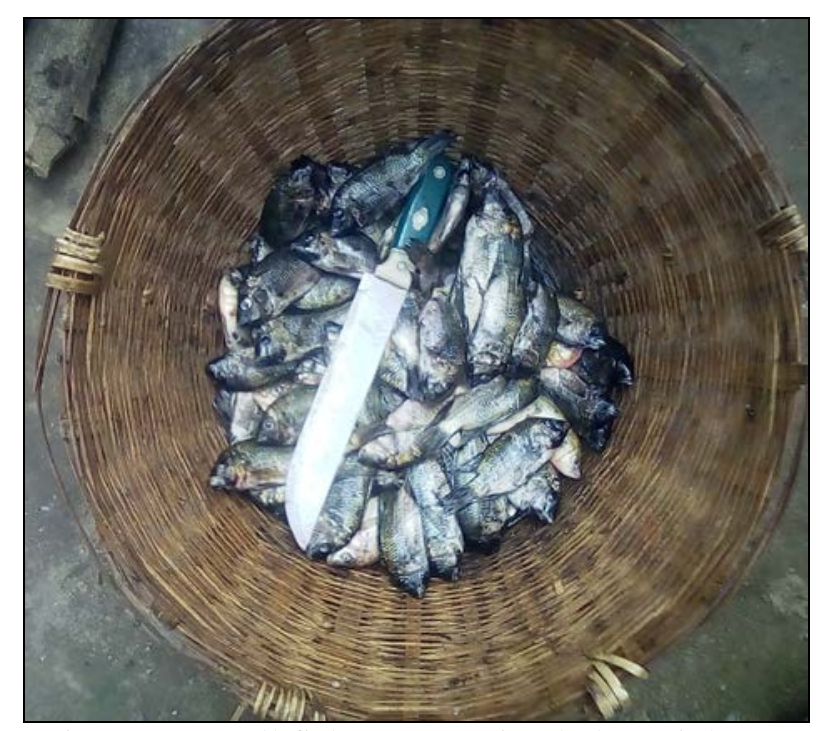

Figure 9: Small fishes measuring below eight $\mathrm{cm}$ caught by the fishermen at Abono.

This disturbing situation is as a result of over-fishing at the lake Bosomtwe. There are no well regulated closed season observed and fishermen constantly engaged in fishing without any strict monitoring system on the harvesting of fishes. This observation made by the researcher confirms what was said by Lamptey (2015) and Nketia et al. (2016) that there is a high rate of overfishing at the Bosomtwe Lake basin, attributing it to the rising population levels that largely depend on the fisheries as sources of livelihood and their impoverished state which were the other identified factors causing the reduction in fish yield. Excessive, unrestrained pressures on the fishes do not allow them adequate time to grow into bigger sizes.

Another recognised factor is the mass destruction of the feeding sites of the young fishes leading to malnutrition affecting their growth pattern and the massive decline of many of the young fish due to lack of food. The phytoplankton that are to be abundant to feed the zooplankton as well as the aquatic macrophytes, benthos, allochthonous fauna and other plant debris have been destroyed by the high levels of phosphorous and nitrate from fertilizers leached from the farmlands in the lake catchment. The destruction is also caused by the huge downpour of domestic sewage, industrial effluents, and soda detergents into the lake from households and guest houses surrounding the lake. As Orighabor (2016) cautioned, if stringent measures are not put in place to arrest these negative human impacts, the aquatic life of all aquatic ecosystems may be destroyed entirely. These situations have been realized at the lake Bosomtwe Catchment and are the causes of the reduction in fish sizes and fish yield. This may be the reason why Abreu et al. (2016) suggested the provision of alternative sources of livelihood for the local residents to ease the pressure on overfishing. 


\section{Fish cost and fish trade}

The reduced sizes of fishes (Fig. 10) and yield have impacted greatly the cost of fish and the fishing trading in general. The fishermen informed the researcher that due to the poor revenue they get from the few fish they catch, they can't effectively take care of their families. This has resulted in a large number of children dropping their education and following their parents for fishing. This was equally realised by Adom et al. (2016a, b). Children in their teens mentioned that their parents could not pay their school fees (four dollars), purchase them school uniforms (two dollars) or buy them textbooks (three dollars). Many of the residents in the Abono community have left to urban centres for greener pastures. Generally, this has reduced the close to sixty communities to twenty two communities currently. The prices of fish are high and the poor rural residents cannot afford them. Therefore, the fish sellers take the few fish they have and try to sell them in the more populous communities. They lamented that the cost of transportation also exerts great toll on their profits. Some of the fish sellers interviewed in a Focus Group Discussion told the researcher that: "we used to buy the fishes at relatively lower costs from the fishermen which we sell for some reasonable profit, but now, they have increased the prices due to the scarcity of the fishes in the Bosomtwe Lake; we used to earn about sixty-five Ghana Cedis (seventeen dollars) a day, but now many of us earn only twentyfive Ghana Cedis (seven dollars); making ends meet is really difficult; many of our colleagues have moved to different areas and entered into other professions because the fishing trade is no more lucrative” (FFG-FGD, Personal Communication, 24 November, 2016).

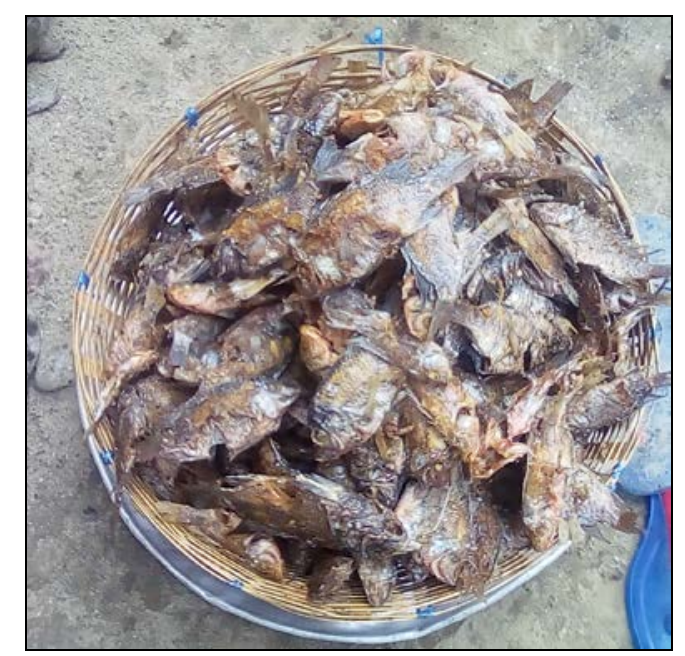

Figure 10: Small fishes fried for sale.

The truism of the findings is supported by the observations made by Adu-Boahen et al. (2015) who mentioned of the massive rural-urban migration affecting the communities surrounding the Bosomtwe Lake due to the lower income levels generated from the fishing. 


\section{Quality of water of the lake Bosomtwe}

Some years ago, due to the sereneness of the Bosomtwe Lake, it was used as the main source of drinking water for the Abono community and the other communities surrounding the lake, as disclosed by some of the elders in the traditional council of Abono to the researcher. Unfortunately, the lake water is no more drinkable due to the negative human impacts (Figs. 11 and 12). The direct washing and bathing in the lake with soda soaps have increased the concentration of nitrates and phosphates, marring the quality of the lake water. The direct discharges of domestic sewage and industrial effluents as well as leaching of chemical fertilizers have increased the level of eutrophication, making the water not potable for drinking. The poor local people have to purchase treated water in rubbers and bottles. The poor who can't afford, drink it and are affected by waterborne diseases like amoebic dysentery and Giardiasis (Adom et al., 2016a, b). Sadly, some visitors who engaged in swimming in the Bosomtwe Lake also complained of skin rashes and this may be as a result of the infiltration of the lake by pollutants from the negative human activities, this may be due to the acidity of the Bosomtwe Lake, below pH 7.0 (Gorde and Jadhav, 2013).

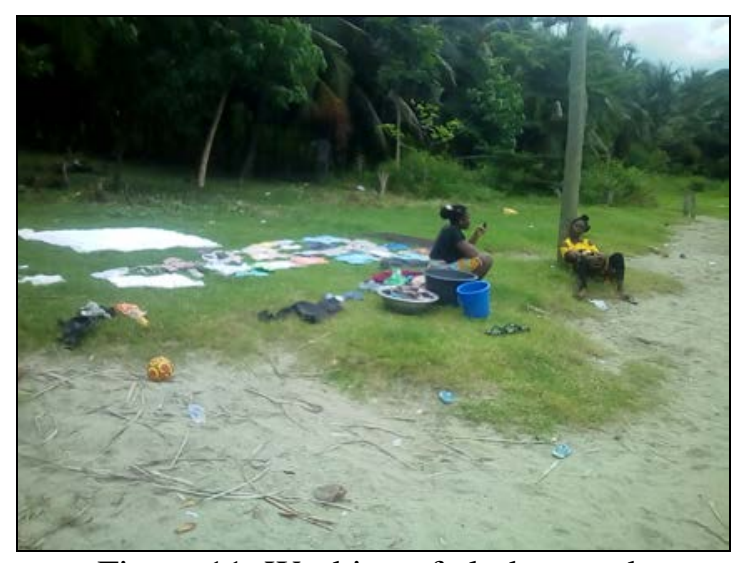

Figure 11: Washing of clothes on the shores of the Bosomtwe Lake

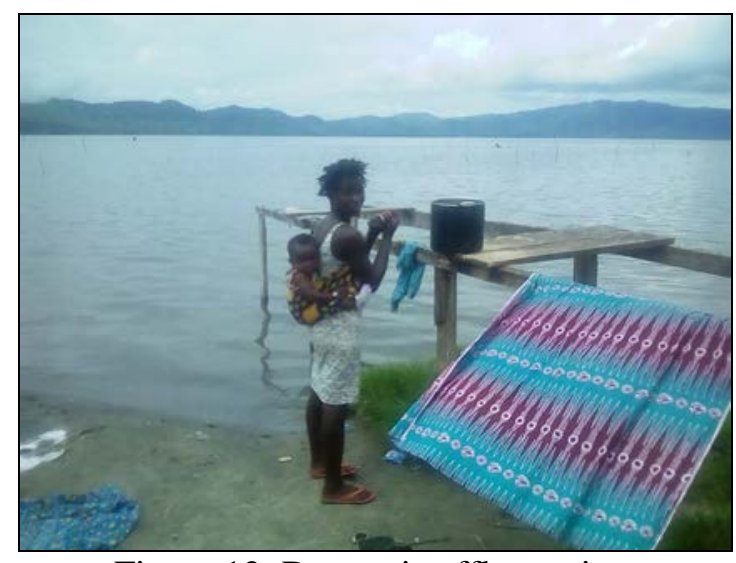

Figure 12: Domestic effluents in Bosomtwe Lake.

The human impacts on the aquatic biodiversity of lake Bosomtwe

The human impacts noticed at the Bosomtwe Lake has been categorised into four main groups: domestic activities, agricultural activities, housing and infrastructure activities and industrial activities (Tab. 3). The respondents expressed great concern about how the weak regulation and monitoring of the activities of residents and visitors to the lake has resulted in gross environmental malfeasance. Some of the elderly respondents, in a focus group discussion disclosed some of the negative actions by some farmers whose farms are on the shores of the lake: "the crop farmers wash their farming implements, containers for their chemical sprayers and pesticides directly into the lake. The Pastoralists also leave their cows, sheep and goats unattended and they wander around the shores of the lake defecating there while grazing the forest vegetation that provides a buffer for the lake” (EER-FGD, Personal Communication, 22 November, 2016). 
These chemical substances introduce high levels of nitrate and phosphates into the lake increasing the mortality rate of fishes due to the destruction of plankton that serves as food for them (Orighabor, 2016). The gradual degradation of the forest vegetation also exposes the lake to soil erosion and high evaporation which destroys the quality of the lake water (Nketia et al., 2016).

The researcher observed the high rate of bush burning from the slash and burn practices of farmers and the burning as well as clearing of forest vegetation in hunting activities for wild animals like grass cutters. This is destructive to the aquatic biodiversity of the Bosomtwe Lake. Anim et al. (2013) reveals that these practices result in atmospheric deposition of high levels of sulphate and nitrate that increases the salination and the acidity of the water. This contamination of the water makes its consumption by the aquatic species very harmful. This explains the reduction in the fish sizes and yield lamented by the residents.

The washing of cars of tourists by the teenagers at the shores of the lake Bosomtwe transfers pollutants directly into the basin. The women wash their clothes, utensils and other household items in lake while throwing residues of leftover foods into the lake. It was observed that residents troop to the lake catchment early morning to bath in the lake using local soaps called Amonkye, Alata samina, Azuma twede which contain high levels of soda (phosphate) deposited in the lake. Others without shame engage in open defecation at the shores of the lake, while others ease themselves in plastics and throw them into the lake at early hours of the day. These practices increase the contamination of the lake. Nketia et al. (2016) concur that such practices reduce the environmental health of aquatic biodiversity.

Table 3: The human impacts on the aquatic biodiversity of lake Bosomtwe; author's construct from the field survey, 2017.

\begin{tabular}{|c|c|}
\hline Negative Human Activities & Associated Impacts on Aquatic Biodiversity \\
\hline 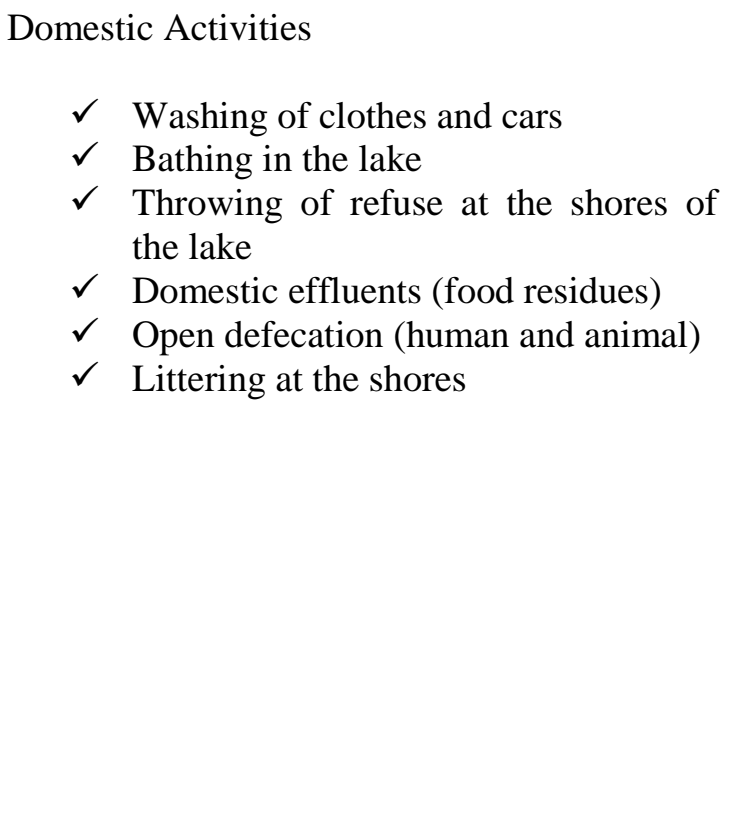 & $\begin{array}{l}\text { High aggregates of nitrate and } \\
\text { phosphate result in the reduction in } \\
\text { plankton that support the lives of } \\
\text { fishes } \\
\text { * High level of eutrophication from } \\
\text { leaching from farmlands into the lake } \\
\text { killing fishes } \\
\text { * The reduction of oxygen in the lake } \\
\text { making life unfavourable for the } \\
\text { fishes who must compete for oxygen } \\
\text { with biodegradable pollutants from } \\
\text { domestic effluents } \\
\text { * Slow strangulation of fishes, amoebic } \\
\text { dysentery and giardiasis } \\
\text { * Water poisoning and acidity } \\
\text { destroying aquatic life }\end{array}$ \\
\hline
\end{tabular}




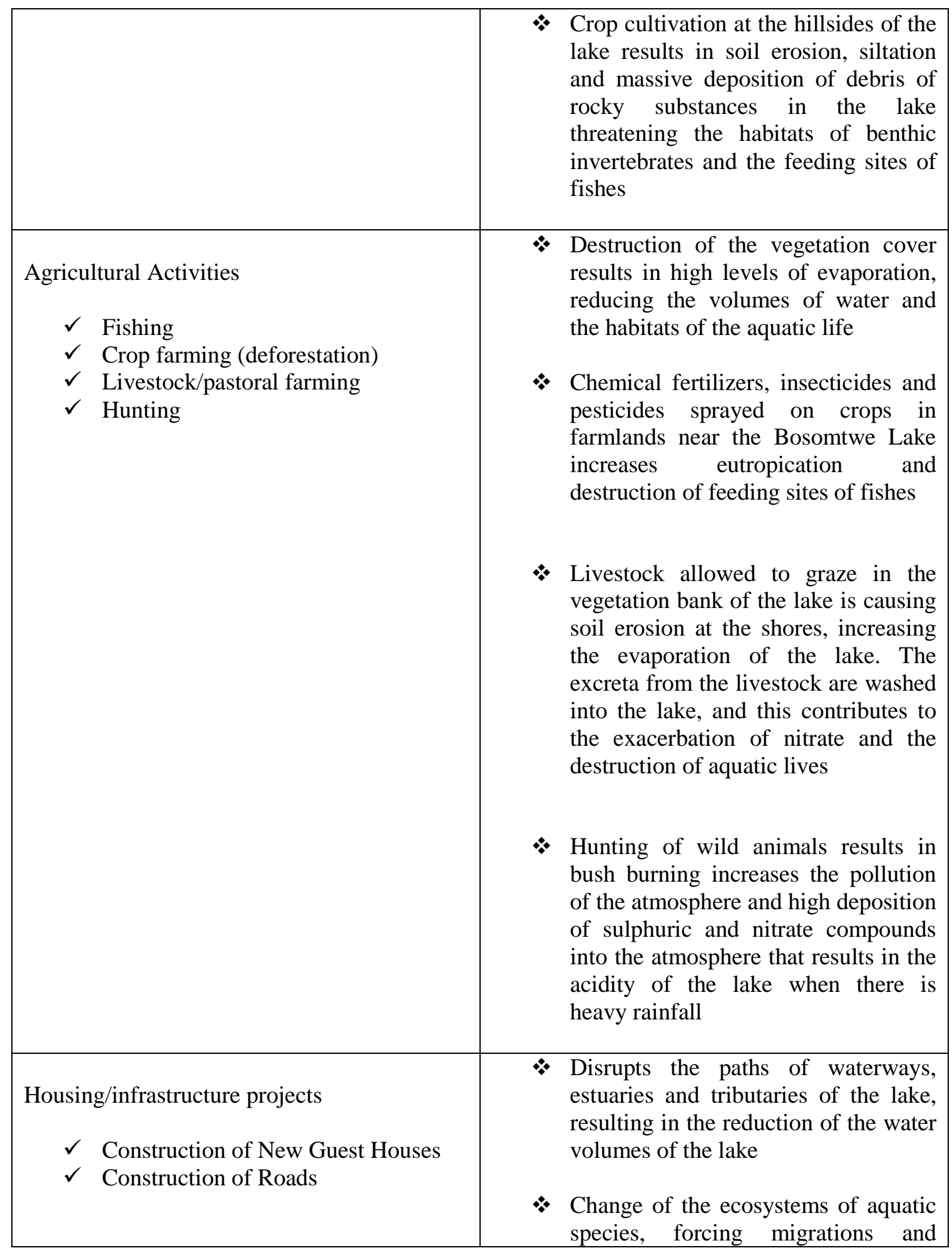




\begin{tabular}{|c|c|c|}
\hline & $*$ & $\begin{array}{l}\text { eventual loss and/or extinction of } \\
\text { particular species of fish } \\
\text { Reduction in the water quality as well } \\
\text { as the species richness of macro- } \\
\text { benthic invertebrates }\end{array}$ \\
\hline 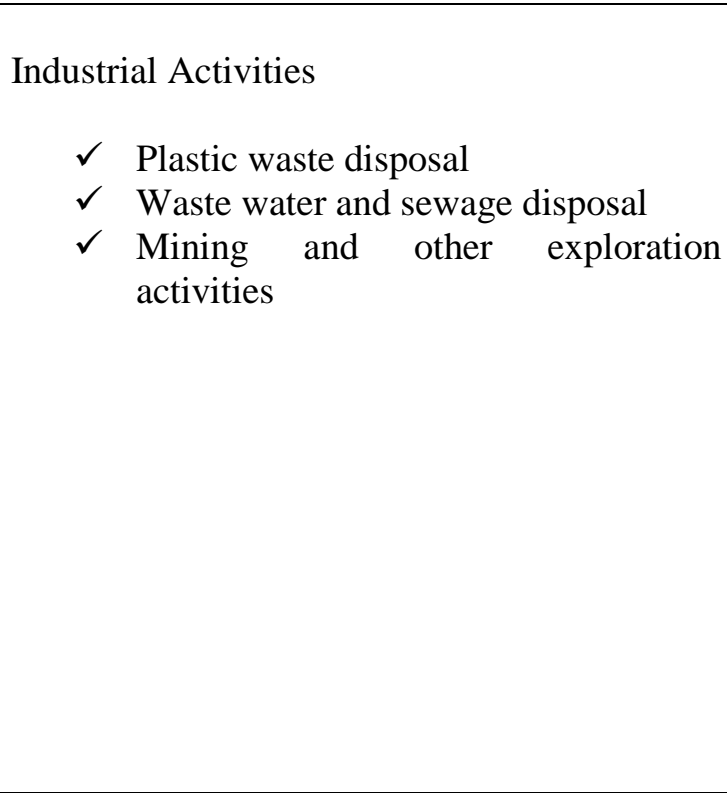 & $*$ & $\begin{array}{l}\text { Industrial waste disposed into the lake } \\
\text { reduces the species richness and } \\
\text { population of the fishes while marring } \\
\text { the potability of the lake water } \\
\text { Introduction of heavy metals and } \\
\text { organochlorines into the lake through } \\
\text { mining operations, threatening the life } \\
\text { sustainability of aquatic species } \\
\text { Chemical agents like Cyanide for } \\
\text { mining close to the shores of the lake } \\
\text { leach into the lake during heavy } \\
\text { rainfall, contaminating both surface } \\
\text { and ground water, increasing its } \\
\text { acidic level, making its consumption } \\
\text { by fishes lethal }\end{array}$ \\
\hline
\end{tabular}

The elderly respondents registered their displeasure at the selling of plots of land closer to the shores of the lake to the infrastructure developers by the traditional council of Abono. These have been used for the construction of guest houses to accommodate visitors at the site for business purposes. However, the poor waste management systems that these construction sites have as well as the eroding of the forest bank, deepens the woes of the aquatic biodiversity of the lake. Some of the lands have been sold to industries and mining firms for operation. As a result, they have constructed roads that distract waterways of the lake. The high soil erosion and the eventual settling of rock sediments into the lake results in habitat destruction, water contamination (Anim et al., 2013), heavy metal deposition, eutrophication and other hazards to the aquatic lives (Mohammed, 2014; Orighabor, 2016). The chiefs and the members of the traditional council of Abono could not provide any tangible reasons for selling the catchment areas of the lake as plots of lands to these industrialists and infrastructure developers. They defended themselves that they did that for developmental reasons. They claimed that it created job avenues for the youth in their community. However, this action, to the researcher, was triggered by selfish interests since many of the employees at those sites were from urban centres. Also, in no way should those plots of land have been given to the developers because they are stepped directly on the thresholds of the lake. Its consequences have rather exacerbated the unemployment rates in the community and more importantly the aquatic biodiversity of the lake. 


\section{Cultural traditions of Abono and the aquatic biodiversity of lake Bosomtwe}

The views of the local residents on the causes of the sorry state of the lake revealed that it was as a result of the relaxed implementation of the cultural traditions of Abono. Many of them believed that the sheer breach of these cultural traditions that served as traditional monitoring systems of the negative human activities on the lake has angered the lake deity (Bosomtwe). Thus, they believed it was the deity who has withheld the bountiful supply of fishes as punishment for disregarding his sacred statutes. The elderly respondents and the residents unanimously admitted: "the owner of the lake, Bosomtwe deity, has been slapped by the actions of our people. The mandatory ceremonial sacrifices of cows, sheep and dogs to him have not been carried out for years by the Asamanhene (Chief of Asaman, A local community around the lake), who is traditionally obliged to do so. In addition, some of the indigenes and, especially, the tourists to our lake flout the precepts, taboos and norms that the deity requires that they are observed. Owing to this, he has also decided to keep his fishes to punish us" (FFE-FGD, Personal Communication, 24 December, 2016).

The breach and failure to observe the cultural traditions are largely blamed on the relaxed attitudes of the Management Council of the lake Bosomtwe as well as chiefs and their traditional council's inability to enforce the cultural traditions. The residents interviewed stated that because of the greediness and irresponsibleness of the Management Council and Traditional Council, they take exorbitant monies from tourists and developers and looks unconcerned at the woes they cause the lake deity when his sacred statutes are infringed. They have sold portions of land closer to the shores which, traditionally, they were not supposed to do. They have folded their arms, watching while the sacredness of the deity and his lake are defiled due to their personal interests. They told the researcher: "both the Management Council of the lake and the Traditional Council are insensitive to the deplorable state of the lake. Many of the former cultural traditions that were held in high esteem by our ancestors are no more effective. Because they (Management Council and Traditional Council) have taken monies to fill their own pockets, they allow the developers and tourists to engage in all forms of environmental malfeasance which are tabooed" (FFE-FGD, Personal Communication, 4 January, 2017).

Probing further, the researcher mentioned the specific cultural traditions that have been breached due to the poor surveillance of the chiefs, Traditional Council and Management Council of the Lake. The feedbacks have been provided in table 4 . 
Table 4: The Cultural Traditions of Abono and Conservation of Aquatic Biodiversity; field survey, 2016.

\begin{tabular}{|c|c|c|}
\hline Cultural Tradition & Activities/Actions Required & $\begin{array}{l}\text { Conservation of Aquatic } \\
\text { Biodiversity by the Standards } \\
\text { of Smith and Wishnie (2000) }\end{array}$ \\
\hline Taboos & $\begin{array}{l}\text { 1. The forest vegetation and } \\
\text { its surrounding lands around } \\
\text { the lake are not supposed to } \\
\text { be encroached. } \\
\text { 2. No bathing, washing and } \\
\text { dumping of any foreign } \\
\text { substance in or around the } \\
\text { shores is allowed. } \\
\text { 3. Having sexual intercourse } \\
\text { in or around the lake is } \\
\text { prohibited. } \\
\text { 4. Women and young girls in } \\
\text { their menstrual cycle are not } \\
\text { supposed to go near the lake } \\
\text { for any activity whatsoever. } \\
5 \text {. No black container } \\
\text { (cooking utensils) } \\
\text { supposed to be sent to the } \\
\text { lake. } \\
6 \text {. No fishing is supposed to } \\
\text { be carried out on taboo days } \\
\text { (Tuesdays and Sundays). } \\
7 \text {. December to April is a } \\
\text { closed season and mass } \\
\text { fishing is prohibited. }\end{array}$ & $\begin{array}{l}\text { 1. The taboo days and closed } \\
\text { seasons restrain harvesting } \\
\text { activities and regulate the } \\
\text { duration of the harvesting of } \\
\text { fishes. It aids in ensuring that } \\
\text { the fishes get adequate time } \\
\text { to procreate and maximize } \\
\text { their numbers and diversities. } \\
\text { Also, it prevents overfishing, } \\
\text { which is a major problem } \\
\text { with the Bosomtwe Lake. } \\
\text { 2. The maintenance of forest } \\
\text { vegetation around the buffer } \\
\text { zones of the lake as well as } \\
\text { construction activities on the } \\
\text { shores of the lake also helps } \\
\text { in preventing all forms } \\
\text { habitat modifications. This } \\
\text { would help in avoiding the } \\
\text { destruction of the feeding } \\
\text { sites (plankton) of the fishes. } \\
\text { 3. The taboos largely ensure } \\
\text { the protection of the aquatic } \\
\text { species. Pollutants and other } \\
\text { environmentally unfriendly } \\
\text { activities banned due to the } \\
\text { taboos would assist in } \\
\text { protecting the rich diversities } \\
\text { of fishes and other forms of } \\
\text { aquatic life in the lake. }\end{array}$ \\
\hline Religious beliefs & $\begin{array}{l}\text { 1. Blocking the water ways of } \\
\text { the lake would incur the } \\
\text { wrath of the lake deity. } \\
\text { 2. Felling trees and clearing } \\
\text { of the forest vegetation would } \\
\text { bring death to one's lineage. } \\
\text { 3. Sacrifices (regular and } \\
\text { periodic) must be performed } \\
\text { for the lake deity. } \\
\text { 4. Everyone would account to }\end{array}$ & $\begin{array}{l}\text { 1. The religious beliefs } \\
\text { imposed the fear of not } \\
\text { incurring the anger of the } \\
\text { deity by engaging in any } \\
\text { form of environmentally } \\
\text { deleterious actions. The } \\
\text { periodic sacrifices renew the } \\
\text { sacredness of the lake and all } \\
\text { its aquatic life. Thus, in no } \\
\text { way would residents engage }\end{array}$ \\
\hline
\end{tabular}




\begin{tabular}{|c|c|c|}
\hline & $\begin{array}{l}\text { the ancestors after their } \\
\text { physical passing, how they } \\
\text { behave towards the resources } \\
\text { in their environment. }\end{array}$ & $\begin{array}{l}\text { in constructional activities } \\
\text { that would modify the } \\
\text { habitats of the lake, its } \\
\text { estuaries and aquatic } \\
\text { biodiversity. } \\
2 \text { The imposition of } \\
\text { accountability after the death } \\
\text { of society members places a } \\
\text { responsibility for each } \\
\text { member of the community, } \\
\text { not to engage in any human } \\
\text { activity that would destroy } \\
\text { the biodiversity species in the } \\
\text { lake and its environs. }\end{array}$ \\
\hline Norms & $\begin{array}{l}\text { 1. The words of the elders in } \\
\text { the community must be } \\
\text { respected and honoured. } \\
\text { 2. The statutes of the chiefs } \\
\text { and Traditional Council must } \\
\text { be observed without any } \\
\text { recourse to objections and } \\
\text { arguments. }\end{array}$ & $\begin{array}{l}\text { The respect for the elderly } \\
\text { that would be heightened } \\
\text { would impact on how the } \\
\text { younger generation heed to } \\
\text { the norms set by the } \\
\text { traditional and management } \\
\text { councils on not engaging in } \\
\text { any activities that would } \\
\text { destroy the aquatic } \\
\text { biodiversity (their habitats, } \\
\text { mitigate their populations and } \\
\text { diversities). }\end{array}$ \\
\hline Moral Values & $\begin{array}{l}\text { 1. The youth must respect the } \\
\text { elderly. } \\
\text { 2. Every resident must desist } \\
\text { from greed and any action } \\
\text { that is triggered by selfish } \\
\text { interests and desires. } \\
\text { 3. The future generation must } \\
\text { always be thought of when } \\
\text { engaging in any action } \\
\text { against the environment. } \\
\text { 4. Humans are stewards of } \\
\text { the environment and would } \\
\text { account to the higher spirits } \\
\text { and ancestors after their } \\
\text { physical death. }\end{array}$ & $\begin{array}{l}\text { Propagating the ideals of } \\
\text { selflessness and a thought } \\
\text { about the future generation } \\
\text { would cultivate in the } \\
\text { younger generation, the need } \\
\text { to respect the closed seasons } \\
\text { while conserving the lake in } \\
\text { its pristine form for the } \\
\text { unborn generations. This } \\
\text { would prevent overfishing } \\
\text { and all forms of habitat } \\
\text { destruction. }\end{array}$ \\
\hline Communal Labour & $\begin{array}{l}\text { 1. The lake deity and } \\
\text { ancestors require that the } \\
\text { entire society is clean and its }\end{array}$ & $\begin{array}{l}\text { The protection of the species } \\
\text { of aquatic biodiversity and } \\
\text { the prevention of habitat }\end{array}$ \\
\hline
\end{tabular}




\begin{tabular}{|l|l|l|}
\hline environment is healthy. & destruction is enhanced \\
2. Participation in communal & $\begin{array}{l}\text { labour is mandatory and } \\
\text { through the communal labour } \\
\text { sailure will be spiritual } \\
\text { sessions. The local people } \\
\text { remove all forms of debris } \\
\text { and pollutants at the shores of } \\
\text { and ancestors while monetary } \\
\text { sanctions and sacrifices } \\
\text { would be required by the lake that would have } \\
\text { Traditional Council. }\end{array}$ & $\begin{array}{l}\text { ended up ausing } \\
\text { eutrophication, maximization } \\
\text { of phosphate and nitrate } \\
\text { levels and so forth. } \\
\text { It would cultivate the ideals } \\
\text { of conservation and } \\
\text { sustainability in residents. }\end{array}$ \\
\hline
\end{tabular}

The people strongly believe that if the cultural traditions are heightened, it would reverse the deplorable state of the lake and assist it to earn its past glory or image. This would call for attitudinal change on the part of the governing class, the local residents and visitors who tour the lake. This is true because the local youth told the researcher that they have refrained from engaging in communal labours, especially at the lake premises because the Traditional Council and the Management Council selfishness take all the proceeds from the site. They do not see the use of the funds profitably to benefit them and the entire community. They lamented that when they are engaged as tourist guides by the Councils, they fail to pay them their due. Thus, they also retaliate by usurping their orders and statutes. This affirms Adom (2016b) assertion that when local people are actively involved in societal issues, they tend to support the activities wholeheartedly. Knowing that they are the cause, the hands of the Councils are tied in punishing the infringers of the cultural traditions. When the researcher questioned the Management Council and the Traditional Council regarding why the cultural traditions are in a relaxed manner, they rather blamed it on the incapacitation of the Asantehene (The king of the sovereign Asante Kingdom) to give proper directives for the full implementation of the cultural traditions of the site. Others also put the blame the influx of Christianity and modernization as asserted by Adom (2016a). Surprisingly, the chief of Abono who is no more staying in the town is accused by the people as not caring for their plight and the condition of the lake. They mentioned that he is wealthy and as such hardly step his foot in the town and whenever he does, it is because he is coming for the revenue from the proceeds of the lake which he has disregarded and left unprotected.

Thus, the findings from the study indicates that the stringent implementation of the cultural traditions of Abono is seen as a potential strategy to salvage the deleterious condition prevalent at the Bosomtwe Lake as asserted by Abreu et al. (2016). Interestingly, these cultural traditions have underpinnings of the scientific methods and have great conservation ethos as Adom (2017) equally noted in his study of the cultural traditions of Anyinam. Therefore, if firm structures are put in place to implement the cultural traditions aside from the scientific strategies it would aid in saving the lake and curtailing all forms of negative human impacts on the aquatic biodiversity of the Bosomtwe Lake. 


\section{CONCLUSIONS}

The study has unearthed the state of the aquatic biodiversity in the Bosomtwe Lake. It has shown that currently, the diversities of the species in the aquatic biodiversity is fast depleting and immediate strategies must be devised to avert the abuse. The human impacts were largely seen in the negative activities of residents and visitors in domestic, industrial, construction, mining and agricultural activities. It is realised from the study that the cultural traditions of Abono have strong conservation ethics for the aquatic biodiversity as have been shown via the assessment using the parameters set by Smith and Wishnie (2000). The relaxed state of the cultural traditions due to the inefficiency in the discharge of the monitoring duties of the chiefs, the Traditional Council and the Management Council of the Lake is a paramount cause of the negative human activities that is destroying the aquatic biodiversity. Also, the lack of support from the local residents and the ignorance of the visitors regarding the cultural traditions have also contributed to the wanton destruction of the aquatic biodiversity of the Bosomtwe Lake. As a result, these recommendations have been forwarded to concerned individuals, groups, agencies and ministries responsible for the upkeep and maintenance of the Bosomtwe Lake and its rich aquatic biodiversity resources:

1. The Ministry of Fisheries and Aquaculture must task the Management Council of the Bosomtwe Lake must increase their monitoring systems and strategies since the lake is part of the aquatic biodiversity heritage of Ghana.

2. The Asantehene (King of the Asante Kingdom) and his cabinet of elders must ensure that the chiefs of Abono, their Traditional Council and the surrounding communities strengthen their governance systems, while enforcing the full implementation of all the cultural traditions of the lake to assist in the preservation of the aquatic biodiversity.

3. The Asantehene must promptly settle all forms of stool disputes to enable the enstoolment of the Asamanhene (Chief of Asaman) who is legally mandated to perform the rituals and ceremonies in connection with the Bosomtwe Lake. This would increase the sacred nature of the lake and psyche the local residents as well as visitors not to defile the lake through the engagement in unhealthy environmental activities.

4. A brochure containing all the cultural traditions that must be observed at the Bosomtwe Lake must be printed and copies distributed to all visitors who tour the site. In addition, orientation sessions must be organized for the visitors and tourists at the site where the cultural traditions are vividly explained with their associated spiritual, sacrificial and monetary penalties. This would mitigate the sheer misconduct at the site on the part of the visitors who in most cases are ignorant of the cultural traditions.

5. The Ministry of Fisheries and Aquaculture must vigilantly supervise the collection of ecotourism revenue at the Bosomtwe Lake so that some of the funds would be utilized for developmental projects including job creation avenues in the Abono community. This would motivate the residents to support all the actions that would ensure the health of the Bosomtwe Lake and its aquatic biodiversity. 
6. The Ministries of Fisheries and Aquaculture, the Forestry Commission, The Ministry of Mines and Energy and the Environmental Protection Agency must liaise to regulate and maintain the strict adherence of farming, fishing, hunting, mining and constructional rules and regulations at the surrounding of the lake. The culprits must be fined and arrested to serve as a deterrent to others not to engage in any form of activity that would be detrimental to the aquatic biodiversity in the lake. All structures and farmlands that illegally occupy the territories of the lake must be demolished and ceased from functioning. These ministries and agencies must also ensure that proper waste management systems that are friendly to the health of the lake, its aquatic biodiversity and environs are maintained by the nearby structures that are not within the catchment area of the Bosomtwe Lake.

7. The Forestry Commission and Environmental Protection Agency must support and intensify the communal labour activities in the Abono community by supplying them with the needed logistics such as refuse containers, brushes, and other cleaning and sanitation tools and materials. Also, they must assist the people to use such platforms for re-planting native flora and mangrove species at the degraded sections of the lake.

8. Some of the local people must be employed as guards at the Bosomtwe Lake so that they can oversee the undertaking of activities at all times (24/7) to report any form of environmental deleterious activity to the Management Council so the culprits would be punished promptly.

9. The Ministry of Fisheries and Aquaculture must organize training sessions for the fishermen at the Bosomtwe Lake to educate them with modern, safe fishing practices while supporting the development of their traditional gadgets for fishing to meet modern standards of fishing.

\section{ACKNOWLEDGEMENTS}

The researcher would like to thank the chiefs and Traditional Council and Management Council of the Bosomtwe Lake as well the all the residents, especially the fishermen in the Abono community who assisted the researcher with the needed data for the study. Special thanks go to the head of the Bosomtwe Range Reserve and the conservationists working in the department for their support in the research. I sincerely thank my research assistants, Mrs. Addai, Mr. Amponsah, and Mr. Adjei for assisting the researcher in conducting the numerous personal and Focus Group Discussion interviews as well as the direct observation of the state of the aquatic biodiversity in the Bosomtwe Lake. 


\section{REFERENCES}

1. Abreu A. D., Salinas A. H. and Clusener-Godt M., 2016- Sustainable management of the lake Bosomtwe in the Ashanti Region of Ghana, France: United Nations Educational, Scientific and Cultural Organization, 46.

2. Adom D., 2016a - Asante indigenous knowledge systems: repositories of conservation ethics for Ghana's biodiversity, Proceedings of the academic conference of Interdisciplinary Approach, 7, 2, Uthman Danfodio University, Sokoto, Ptf I Hall, Sokoto, Sokoto State, Nigeria, 8-36.

3. Adom D., 2016b - Inclusion of local people and their cultural practices in biodiversity conservation: lessons from successful nations, American Journal of Environmental Protection, 4, 3, 67-78, doi: 10.12691/env-4-3-2.

4. Adom D., 2017 - Promoting cultural traditions, social inclusion and local community participation in environmental development schemes promoting cultural traditions, social inclusion and local community participation in environmental development schemes, Global Journal of Science Frontier Research: Environment and Earth Science, 17, 2.

5. Adom D., Dzakpasu P. E. and Adam S., 2017 - Cultural practices of local communities as a biodiversity managerial strategy for Ghana's environment: a retrospection of international conventions, International Journal of Scientific Research, 6, 5, 332-341.

6. Adu-Boahen K., Dei Leud A., Antwi, K. B. and Adu-Boahen, A. O., 2015 - Shoreline change detection of lake Bosomtwe, Ghana, evidence from historical and meteorological records, Journal of Arts and Social Sciences, 3, 1, 18-42.

7. Anim O. D., Li Y., Agadzi A. K. and Nkrumah P. N., 2013 - Environmental issues of lake Bosomtwe impact crater in Ghana (West Africa) and its impact on ecotourism potential, International Journal of Scientific and Engineering Research, 4, 1.

8. Asamoah E., Nketia K. A., Sadick A., Gyambibi D. A., Forkuo E. K., Ayer J. and Adjei E. O., 2015 - Water quality assessment of lake Bosomtwe for irrigation purpose, Ghana, International Journal of Agriculture and Crop Sciences, 8, 3, 366-372.

9. Bradley C., Emmet D. J., and Gonzalez A., 2012 - Biodiversity loss and its impact on Humanity, Nature, 486, 7401, doi:10.1038/nature11148, PMID 22678280, 59-67.

10. Dassah A. L. and Agbo N., n. d. - Lake Bosomtwe fisheries: the threats to biodiversity and livelihoods in the Bosomtwe Basin, KNUSTSPACE: Department of Freshwater Fisheries and Watershed Management, 1-6.

11. Denzin N. K. and Lincoln, Y. S., 1994 - Introduction: entering the field of qualitative research, in Denzin N. K. and Lincoln Y. S., (eds) Handbook of qualitative research, Thousand Oaks: Sage Publications, 1-17.

12. Fade S., 2004 - Using interpretive phenomenological analysis for public health nutrition and dietetic research: A practical guide, Proceedings of the Nutrition Society, 63, 647-653.

13. Fisheries Regulations of Ghana, 2010 - Ministry of Fisheries and Aquaculture: Government of Ghana, 46.

14. Fraenkel J., Wallen N. and Hyun H., 2012 - How to design and evaluate research in Education, (8th edition), New York: Mc Graw-Hill Companies, 707.

15. Gorde S. P. and Jadhav M. V., 2013 - Assessment of water quality parameters: a review, Journal of Engineering Research and Applications, 3, 6, 2029-2035.

16. Harden G., 1968 - The tragedy of the commons, Science, 162, 1, 239-257.

17. Helfrich L. A., Neves R. J., Parkhurst J., 2009 - Sustaining America's aquatic biodiversity, What is biodiversity; Why is it important? Communications and Marketing, College of Agriculture and Life Scences, Virginia Polytechnic Institute and State University, retrieved from http://www.ext.vt.edu (accessed 3/6/2016).

18. Hogan R., 2010 - Protected areas for a living planet, W.W.F. International, Nagoya, Japan, $1-2$. 
19. Jones W. B., Bacon M. and Hastings D. A., 1981 - The Lake Bosomtwe Impact Crater, Ghana Geological Society of America Bulletin, 8, 1-392.

20. Khoshnood Z., 2017 - Effects of environmental pollution on fish: a short review, Transylvanian Review of Systematical and Ecological Research - The Wetlands Diversity, 19.1, 49-60.

21. Kumekpor K. B., 2002 - Research Methods and Techniques of Social Research, Ghana: SonLife Printing Press and Services, 304.

22. Lamptey E., 2015 - Eco-Functional Benthic Biodiversity Assemblage Patterns in the Guinea Current Large Marine Ecosystem, Physical and Life Science Series, 2, Department of Marine and Fisheries Sciences Reader, University of Ghana, 314.

23. Leedy P. D. and Ormrod J. E., 2010 - Practical Research: Planning and Design (9th edition), Upper Saddle River, New Jersey: Pearson Education, Inc., 67.

24. Lewis J. L. and Sheppard S. R. J., 2006 - Culture and Communication: Can Landscape Visualization Improve Forest Management Consultation with Indigenous Communities? Landscape and Urban Planning, 77, 291-313.

25. Mohammed A. K., 2014 - Tourism Development Policy versus Practice in Ghana: The Case of Lake Bosomtwe Basin, European Scientific Journal, 10, 7, 27.

26. Moon P. A. and Mason D., 1965 - The Geology of the $1 / 4$ Field Sheets 129 and131, Bompata S. W. and N. W., Ghana Geological Survey Bulletin, 31, 1-51.

27. Nketia K. A., Asamoah E., Sadick A., Asenso-Gyambibi D. and Forkuo E. K., 2016 Assessment of Water Quality of Lake Bosomtwe for Recreational Purposes, International Research Journal of Agricultural and Food Sciences, 1, 5, 108-114.

28. Orighabor B. J., 2016 - Impact of Human Activities on Biodiversity in Nigerian Aquatic Ecosystems, Science International, 4, 12-20.

29. Otu M. K., 2010 - The Origin, Transformation and Deposition of Sediments in Lake Bosomtwe (Ghana/West Africa). Doctoral Dissertation, University of Waterloo, Ontario, Canada, 200.

30. Pietkiewicz I. and Smith J. A., 2014 - A Practical Gude to Using Interpretative Phenomenological Analysis in Qualitative Research Psychology, Psychological Journal, 20, 1, 2014, 7-14.

31. Pope C., Ziebland S. and Mays N., 2000 - Qualitative Research: Analysing Qualitative Data, British Medical Journal, 320, 114-116.

32. Shah A., 2014 - World's Biodiversity Crisis, http://www.globalissues.org, (accessed 2015 October 3), 1-3.

33. Smith E. A. and Wishnie M., 2000 - Conservation and Subsistence in Small-Scale Societies, Annual Reviews Anthropology, 29, http://dx.doi.org/10.1146/annurev.anthro.29.1.493, 493-524.

34. Smith J. A. and Osborn M., 2008 - Interpretive Phenomenological Analysis, in Smith J. (ed.), Qualitative Psychology, A Practical Guide to Research Methods, London: SAGE, 53-80.

35. Whyte S. A., 1975 - Distribution, Tropic Relationship and Breeding Habits of the Fish Populations in a Tropical Lake Basin (Lake Bosomtwe- Ghana), Journal of Zoology London, 177, 25-26.

36. Wilder B. T., O’meara C., Monti L. and Nabhan G. P., 2016 - The Importance of Indigenous Knowledge in Curbing the Loss of Language and Biodiversity, Bioscience, 66, 449-509, doi:10.1093/biosci/biw026, 66, 6.

37. W.W.F., 2016 - Living Planet Report. Retrieved from http://www.wwf.panda.org (accessed 12/7/2016), 1-2. 